

\title{
Perfect Pitch
}

\section{By Franziska Buttgereit}

\begin{abstract}
Mozart had perfect pitch, as did Beethoven, Bach, and Jimi Hendrix. However, this ability does not a gifted musician make, as studies continually show that prodigies and amateurs alike may are capable of it.
\end{abstract}

Researchers have been studying the phenomenon of perfect pitch for years. For example, Diana Deutsch, a music psychologist from the University of San Diego, California, concludes that anyone can have perfect pitch - you just have to learn Cantonese or Mandarin early enough. These languages are tonal languages, where precise speaking and exact hearing are important, as the same words can have completely different meanings at different pitches. As an example, Deutsch lists the syllable, "Ma", which, depending on the tone, may mean mother, horse, hemp, or even reproach. Perfect pitch develops naturally alongside normal speech. Other such tonal languages include Asian languages such as Thai or Lao, and Standard Chinese, as well as African regional languages such as Swahili, Xhosa or Bantu. Clearly, China represents but one example in which absolute pitch generally shared among 1.2 billion people suggests that tonal languages must have something to do with one's relationship to sound. There are regions throughout Asia in which almost every second person has perfect pitch, but musical geniuses they are not, says Deutsch, because the ability is neither a sign of pronounced musical talent, nor is it particularly rare. 
A person with perfect pitch is able to determine the frequency of any tone and correctly place it in a tonal system without the need for a comparison tone. One can tune each song to the correct pitch, whereby the "normal" listener needs comparison tones in order to be able to classify the sound correctly in a system. Approximately 1 in 10,000 people in North America and Europe have perfect pitch. It is still, however, quite unexplored what conditions the brain needs for this. What has been found in all of the people with perfect pitch is that a certain brain area, the planum temporale, in which sounds are processed, is greatly enlarged on the left side. The halves of the brain are much more symmetrical in people who do not have the ability. Thus, perfect sound recognition is an expanded brain function and has nothing to do with normal hearing.

In 2006, Ms. Deutsch compared the hearing of Mandarin-speaking members of the Beijing Music Conservatory with that of English-speaking students at the Eastman School of Music in Rochester, NY. Depending on the age at which the test subjects started learning their respective instruments, up to $60 \%$ of the Chinese students had absolute hearing. The American figure was only $14 \%$. The best results in the study were achieved by the students who had received their first musical lessons at the age of four to five years old. Of those who had only started music school at the age of 8 or later, none of the native English speakers had absolute hearing, whereas at least $42 \%$ of the Mandarin speakers did. This rather clearly shows the great influence the mother tongue has on one's development of perfect pitch.

Neuroscientists believe that early music education promotes a functional restructuring of the hearing center of the brain. It remains controversial whether the chance to develop perfect pitch depends on the genes of the parents or, as medical examinations show, that all people are innately capable of developing it. Nelson Freimer, professor of psychiatry at the University of Los Angeles in California, tested 500 musicians with and without perfect pitch. He found that half of the subjects with the ability had other family members with it as well. In comparison, only $5 \%$ of the musicians without perfect hearing had family members with perfect hearing. In further tests, it was found that the heritability of perfect pitch, similar to body size, is 70 to 80 percent. Children whose 
siblings have perfect pitch have a 15 times greater chance of having it than those who have no one with perfect pitch in the family.

The extent to which genetics have an impact on perfect pitch is still not entirely understood. It is, of course, worth asking, why does one need perfect pitch in the first place? According to a theory by researchers, it helps babies learn to speak. Once this is done, the ability is no longer important, which is why most lose it with age. Acquiring perfect pitch after childhood does not seem possible even with extensive training, however violinists could be possible exceptions. Because they tune their instruments relative to $A$ at 440 Hertz several times a day, this tone becomes a very strong association for many players. It is important to note that one cannot develop true perfect pitch through memory, no matter how intensely one trains.

Thus, from birth, everyone has what it takes to develop perfect pitch. However, whether we really learn to hear absolutely depends on ourselves and on our parents.

\section{About the author:}

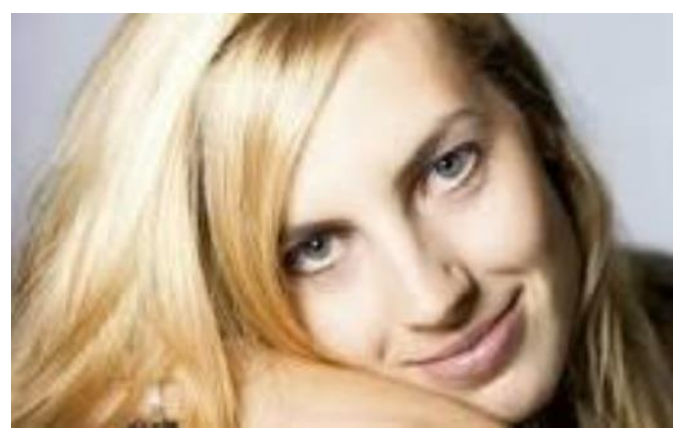

Franziska Buttgereit (Mezzosopranistin) Die Mezzosopranistin Franziska Buttgereit ist seit 2010 Mitglied des Extrachors des Theaters Freiburg und seit 2017 dessen erste Direktorin. Im Jahr 2015 begann sie ihr Gesangsstudium bei Prof. Christiane Libor an der Musikhochschule Schloss Gottesaue in Karlsruhe und arbeitet seitdem mit der Hochschule für Musik und dem Stadttheater Freiburg zusammen, was zu einer kleinen Rolle in Aufführungen und der gleichnamigen DVD-Produktion "Cendrillon" von Jules Massenet geführt hat.

// Franziska Buttgereit is a mezzo-soprano who has been a member of the Freiburg Theatre's extra choir since 2010 and its first director since 2017. In 2015 she began her singing studies with Prof. Christiane Libor at the Musikhochschule Schloss Gottesaue in Karlsruhe and has been collaborating with the University of Music and the Stadttheater Freiburg, which has led to a small role in performances and the DVD production of the same name "Cendrillon" by Jules Massenet. 